\title{
The relationship between Marcel Proust and Joseph Babinski: the encounter of two geniuses
}

\author{
A relação entre Marcel Proust e Joseph Babinski: o encontro de dois gênios \\ José Luiz Pedroso ${ }^{1}$, Orlando G. P. Barsottini ${ }^{1}$, Hélio A. G. Teive ${ }^{2}$, Francisco Cardoso ${ }^{3}$
}

\begin{abstract}
Marcel Proust was one of the greatest French writers of all times. Since early in his life, Proust was interested in arts and particularly literature. He also demonstrated a great knowledge of medicine, particularly neurology. His father was a doctor, and contributed to neurology through studies on aphasia, stroke, hysteria, and neurasthenia. During his childhood, Proust had the first asthma attack, initially considered a manifestation of neurasthenia. Regarding his illness, Proust was in touch with several renowned neurologists, such as Brissaud, Babinski and Sollier, and other disciples of Charcot. Proust spent the last three years of his life mostly confined to his bedroom since his health had badly deteriorated. In one moment, Babinski was called, examined Proust and after leaving his bedroom, announced to his brother that Proust was practically dead. Few hours later, Proust developed vomica and died.
\end{abstract}

Keywords: Marcel Proust, Joseph Babinski, neurasthenia, neurology.

\section{RESUMO}

Marcel Proust foi um dos maiores escritores franceses de todos os tempos. Desde jovem, Proust era interessado em artes e especialmente literatura. Ele também demonstrava um grande conhecimento sobre medicina, especialmente neurologia. Seu pai era um médico, e contribuiu para a neurologia através de estudos sobre a afasia, acidente vascular cerebral, histeria, neurastenia. Durante sua infância, Proust teve o primeiro ataque de asma, inicialmente considerado uma manifestação da neurastenia. Devido à sua doença, Proust estava frequentemente em contato com vários neurologistas renomados, tais como Brissaud, Babinski e Sollier, entre outros discípulos de Charcot. Proust passou a maior parte do tempo nos últimos três anos da sua vida confinado em seu quarto, após deterioração da sua saúde. Em um determinado momento, Babinski foi chamado, examinou Proust e depois de sair de seu quarto, anunciou a seu irmão que Proust estava praticamente morto. Poucas horas depois, Proust desenvolveu vômica e faleceu.

Palavras-chave: Marcel Proust, Joseph Babinski, neurastenia, neurologia.

Marcel Proust (1871-1922) was one of the greatest French writers of all times. Since early in his life, Proust was interested in arts and particularly literature. He also demonstrated a great knowledge of medicine, especially neurology. His father was a doctor (pathologist and epidemiologist), and contributed to neurology through studies on aphasia, stroke, hysteria, and neurasthenia ${ }^{1}$. By the age of nine, Proust had the first attack of asthma that would plague him throughout his life.

Regarding his illness, Proust was in touch with several renowned neurologists, such as Babinski and Sollier, and other disciples of Charcot. Proust's disease was supposed to have a "nervous" (i.e., psychogenic) origin and this assumption was reflected in his writings. Brissaud was the first to conclude that his asthma was a manifestation of neurasthenia. Interestingly, this neurologist published a book on asthma entitled "The health of asthmatics", which was prefaced by Proust's father ${ }^{2}$.

Although Proust was son and brother of famous physicians, he held ambiguous views of medical doctors, often depicted as incompetent and superficial:

"Medicine is a compendium of all sequential and contradictory errors of doctors".

This was at least in part consequence of the difficult relationship he had with his father ${ }^{3}$. The following passage of his masterpiece, In Search of Lost Time, illustrates this point:

${ }^{1}$ Departamento de Neurologia, Setor de Neurologia Geral e Ataxias, Universidade Federal de São Paulo, Sao Paulo SP, Brazil;

${ }^{2}$ Setor de Distúrbios de Movimento, Serviço de Neurologia, Hospital de Clínicas, Universidade Federal do Paraná, Curitiba PR, Brazil;

${ }^{3}$ Setor de Distúrbios de Movimento, Serviço de Neurologia, Departamento Interno de Medicina, Universidade Federal de Minas Gerais, Belo Horizonte MG, Brazil. Correspondence: Francisco Cardoso; Av Pasteur, 89/1107; 30150-290 Belo Horizonte MG, Brasil; E-mail: cardosofe@terra.com.br

Conflict of interest: There is no conflict of interest to declare.

Support: Pedroso JL, Barsottini OG and Teive HAG have nothing to disclose. Cardoso F: honoraria from Roche and Medtronic as well as research grant from FAPEMIG.

Received 18 February 2014; Accepted 13 March 2014. 
"My suffocations having persisted long after any congestion remained that could account for them, my parents brought in Professor Cottard. It is not enough that a physician who is called in to treat cases of this sort should be learned. Confronted with symptoms which may be those of three or four different complaints, it is in the long run his flair, his instinctive judgment that must decide with which, despite the more or less similar appearance of them all, he has to deal. This mysterious gift does not imply any superiority in the other departments of the intellect, and a person of the utmost vulgarity, who admires the worst pictures, the worst music, who is without the slightest intellectual curiosity, may well possess it"4.

In 1918, for the first time, Proust consulted Joseph Babinski, due to speech disturbances. He became terrified of developing a stroke, like his mother ${ }^{5}$. Joseph Babinski's life spanned a period of great change in France, particularly in the field of Neurology. Babinski received his medical degree from the University of Paris in 1884, and became an impressive clinician. He painstakingly examined patients with neurological diseases, and his techniques helped to create the method for neurological examination. Free of teaching duties allied to professorship, he worked at the Hôpital de la Pitié and focused on clinical neurology. Of note, the Babinski sign is the most widely appreciated and globally entrenched eponym in Neurology. During his professional life, Babinski devoted time to the study of tendon reflexes, cerebellar disorders and identification of new neurological treatments for his patients ${ }^{6}$.

Proust's correspondence provides interesting glimpses of how he perceived doctors. The following excerpts demonstrate Proust's first impressions of Babinski:

(i) "a famous consultant, whose diagnosis concerning the point that tormented me has been relatively favorable. What remains is to know if he is sincere";

(ii) "Babinski told me it was not éphanie; but you never know if doctors want to mislead you or mislead themselves"6.

Babinski had previously treated Proust's mother for hemiplegia with aphasia ${ }^{2,3,4,5,6}$. In 1921, Proust again consulted Babinski, fearing he was losing his memory, which would render him incapable of finishing writing his book.

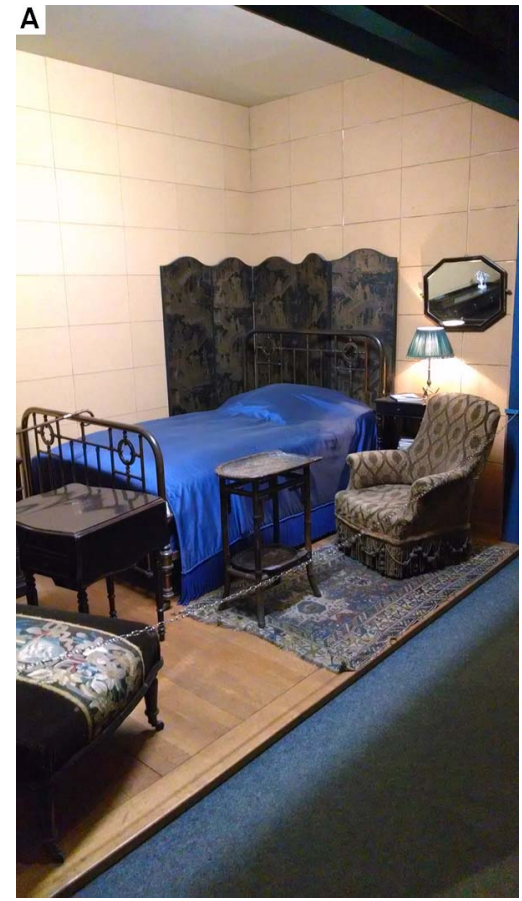

Figure. Marcel Proust's bedroom as it stands reconstituted at the Musée Carnavalet in Paris (picture provided by the authors).

Babinski, after asking him to repeat "constantinopolitain and artilleur de l'artillerie", diagnosed that his complaints were caused by hypnotic drug abuse (Veronal) ${ }^{6}$.

Proust spent the last three years of his life mostly confined to his bedroom (Figure), sleeping during the day and working at night to complete In Search of Lost Times. One day his brother, Robert Proust, pioneer of urology in France, paid a visit to him in his flat and found him ill, feverish and with symptoms suggestive of a lung infection. In despair, he asked Proust's faithful servant, Celeste Albaret, why he had left the apartment late in a cold night. The writer's health rapidly deteriorated, developing symptoms suggestive of pulmonary abscess. Babinski had a reputation of being not only an excellent neurologist, but an outstanding internist as well. Because of that, as a last resource Robert Proust summoned him to do a home call on Proust on $18^{\text {th }}$ of November of 1922. According to the memoirs of Madame Albaret, Babinski went to Proust's flat, examined him and after leaving his bedroom, announced to Robert that Proust was practically dead. In fact a few hours later, Proust developed vomica and died?
1. Bogousslavsky. Marcel Proust's diseases and doctors: the neurological story of a life. Front Neurol Neurosci 2007;22:89-104.

2. Bogousslavsky. Marcel Proust's lifelong tour of the Parisian Neurological Intelligentsia: from Brissaud and Dejerine to Sollier and Babinski. Eur Neurol 2007;57:129-136.

3. Painter GD. Marcel Proust: A biography. New York, 1989.
5. Bogousslavsky. Marcel Proust's fictional diseases and doctors. Front Neurol Neurosci 2013;31:245-254

6. Philippon J, Poirier J. Joseph Babinski: a Biography. Oxford University Press, New York, 2009.

7. Albaret C. Monsieur Proust. Translation by Barbara Bray. New York, 2003. 